\title{
Analysis of Geotechnical Engineering Safety Technology in Urban Underground Space Construction
}

\author{
Yun Wan ${ }^{*}$, Yaoping Luo ${ }^{2}$ \\ 1Zhongdu Engineering Design Co., Ltd., Southwest Branch, Chongqing 400064, China \\ ${ }^{2}$ China Railway Changjiang Transport Design Group Co., Ltd., Chongqing 401147, China \\ *Corresponding author: Yun Wan, 503463225@qq.com
}

Copyright: ( $) 2022$ Author(s). This is an open-access article distributed under the terms of the Creative Commons Attribution License (CC BY 4.0), permitting distribution and reproduction in any medium, provided the original work is cited.

\begin{abstract}
With the accelerating pace of urbanization, the development and application of urban underground space has attracted much attention. In the construction of urban underground space, geotechnical engineering safety is the key point for construction. Based on this, this paper analyzes the application of geotechnical engineering safety technology in urban underground space construction, in hope that this analysis can provide a scientific reference for the rational application of geotechnical engineering safety technology as well as the construction and development of urban underground space.
\end{abstract}

Keywords: Urban construction; Urban underground space; Geotechnical engineering; Safety technology

Online publication: January 12, 2022

\section{Introduction}

In the construction of urban underground space, in view of its special engineering environment, there are challenges in its safety control. In this case, the construction unit needs to strengthen the research on its safety technology and reasonably apply corresponding geotechnical engineering safety technology while taking into consideration of the actual engineering situation and construction requirements. In this way, the safety of urban underground space construction can be well guaranteed to meet the actual construction and application needs of underground space.

2. Analysis of geotechnical engineering and its safety management characteristics in urban underground space construction

\subsection{Overview of geotechnical engineering in urban underground space construction}

In the development and construction of urban underground space, geotechnical engineering is an important aspect. At present, the geotechnical engineering of urban underground space mainly includes foundation pit engineering and tunnel engineering. The main feature of this kind of project is that the construction environment is poor, there are many uncertain factors in the construction, and it has high risk. In the geotechnical engineering of urban underground space construction, if its construction safety cannot be well guaranteed, major safety accidents may occur, which then result in serious economic losses and even casualties ${ }^{[1-3]}$. Based on this, in the specific underground space geotechnical engineering construction 
process, the construction unit must pay enough attention to its safety technology and ensure the safety of the whole project through the reasonable application of safety technology.

\subsection{Main characteristics of geotechnical engineering safety management}

During the construction of urban underground space, the safety management characteristics of geotechnical engineering mainly include three aspects: the first is diversity; the second is mobility; and the third is chronicity. Table 1 is an analysis of these three main features and their specific conditions.

Table 1. Main characteristics and details of geotechnical engineering safety management in urban underground space construction

\begin{tabular}{cll}
\hline Number & Features & \multicolumn{1}{c}{ Specific situation } \\
\hline 1 & Diversity & $\begin{array}{l}\text { The overall project construction scale is relatively large, there are many participating units, the safety } \\
\text { management is complex, and the management methods at all levels are different. } \\
\text { There are many divisional and subdivisional works involved; there are many processes in each } \\
\text { subdivisional work. In order to ensure on-schedule completion, the mobility of mechanical equipment } \\
\text { and construction personnel is relatively large. } \\
\text { The overall construction period is relatively long, safety problems may occur at any time, and safety } \\
\text { guarantee needs to be done in specific applications; therefore, long-term safety management is } \\
\text { Chronicity } \\
\end{array}$ \\
&
\end{tabular}

\section{Application of geotechnical engineering safety technology in urban underground space construction}

\subsection{Application of environmental safety technology}

In the process of geotechnical engineering construction of urban underground space, environmental safety is the key. Therefore, the construction unit must strengthen the research on environmental safety technology and strictly implement it in specific construction. For example, in the construction of underground deep foundation pit in urban space, the construction unit should control its environmental safety through the following technical measures: first, all mechanical equipment should be placed in strict accordance with the specified distance during construction to avoid mutual influence due to excessive distance of mechanical equipment; second, all engineering materials should be sorted and placed neatly, and the placement height must be controlled within a specified limit, which should be consistent with relevant safety technical standards, without affecting the normal operation of mechanical equipment on the construction site; third, the construction site ground should be kept clean, sundries, garbage, and oil stains should be cleaned in time, and emphasis should be on the production control of pollutants during construction. All pollutants generated should be treated in a centralized manner, waste heat and waste water should be recycled, and solid waste as well as waste gas should be reasonably disposed in accordance with the relevant provisions of "Environmental Management Procedure." In addition, clean construction technology should be selected as much as possible during the preparation of the construction scheme ${ }^{[4]}$.

\subsection{Application of mechanical equipment safety technology}

In the construction of urban underground space, mechanical equipment is the key to geotechnical engineering construction. In particular, underground geotechnical engineering itself has strong particularity, and many mechanical equipment is required in its construction. It needs to be applied to some special mechanical equipment, such as cutting machines, cranes, and pressure vessels, which are relatively 
dangerous. Once problems occur, there is a high possibility of major safety accidents and immeasurable losses. Based on this, in the specific application of geotechnical engineering safety technology, the construction unit must pay attention to the reasonable application of construction equipment safety technology. In this process, first of all, it is necessary to make a reasonable selection of mechanical equipment in strict accordance with the engineering design and actual needs as well as standardize the operation technical process and safety precautions of each mechanical equipment. Second, before the mechanical equipment enters the construction site, the quality inspection personnel must inspect it in a strict manner. The mechanical equipment account should be established and improved. It can only be allowed to enter the construction site when the quality and performance of the mechanical equipment fully meet the engineering requirements and standards. The third is to ensure that every mechanical equipment operator works with a certificate. For new mechanical equipment, the pre-job training for operators needs to be emphasized. If necessary, professional technicians should be arranged to provide on-site guidance to ensure the application effect and safety when using the mechanical equipment as well as to avoid safety accidents caused by improper operation. The fourth is to ensure that the regular maintenance and daily maintenance of the mechanical equipment are effectuated well. This should be under the responsibility of professional maintenance technicians. Through daily maintenance and regular maintenance, the abnormalities of the mechanical equipment can be determined in time and dealt with effectively, thus avoiding the safety problems caused by mechanical equipment faults ${ }^{[5-7]}$.

\subsection{Application of support safety technology}

In the construction of urban underground space, good support is the key to ensure the safety of geotechnical engineering construction. Based on this, the construction unit needs do a good job in the underground geotechnical engineering support according to the actual situation and reasonably apply its safety technology in its support. In this process, it is first necessary to reasonably select the type of support. In the selection, the support technology should be determined according to the following conditions: the first is to scientifically evaluate the main types of rock mass; the second is to evaluate the adaptability of rock mass category change; the third is to evaluate the adaptability of rock mass under special or great ground pressure conditions; the fourth is to evaluate the adaptability of groundwater properties; the fifth is to evaluate the economy of the support technology; the sixth is to evaluate the operation time of support construction. Only on the basis of ensuring that the above evaluation results meet the actual engineering conditions and construction requirements, then the corresponding support technology can be selected to ensure the safety of geotechnical engineering construction in urban underground space ${ }^{[8]}$. For example, during the construction of urban underground tunnel, its geotechnical support structure and its basic application are shown in Table 2. 
Table 2. Supporting structure and its basic application in urban underground tunnel construction

\begin{tabular}{|c|c|c|c|c|c|c|c|c|c|}
\hline \multirow[b]{2}{*}{$\begin{array}{l}\text { Requirement } \\
\text { Support type }\end{array}$} & \multicolumn{3}{|c|}{ Hybrid support } & \multicolumn{3}{|c|}{ Concrete support } & \multirow{2}{*}{$\begin{array}{c}\text { Anchor bolt } \\
\text { and metal } \\
\text { mesh } \\
\text { support }\end{array}$} & \multirow{2}{*}{$\begin{array}{c}\text { Steel } \\
\text { structure } \\
\text { support }\end{array}$} & \multirow{2}{*}{$\begin{array}{c}\text { Wood } \\
\text { structure } \\
\text { support }\end{array}$} \\
\hline & $\begin{array}{c}\text { Shotcrete } \\
\text { anchor steel } \\
\text { support back } \\
\text { plate }\end{array}$ & $\begin{array}{c}\text { Shotcrete } \\
\text { anchor steel } \\
\text { support short } \\
\text { anchor rod }\end{array}$ & Steel support & $\begin{array}{l}\text { Concrete } \\
\text { spraying } \\
\text { support }\end{array}$ & $\begin{array}{l}\text { Guniting } \\
\text { support }\end{array}$ & $\begin{array}{c}\text { Protective } \\
\text { concrete } \\
\text { support }\end{array}$ & & & \\
\hline Drainage conditions & Available & Very good & Very good & Very good & $\begin{array}{c}\text { Not } \\
\text { considered }\end{array}$ & Appropriate & Very good & Available & Very good \\
\hline $\begin{array}{l}\text { Adaptive confrontation } \\
\text { of track shape }\end{array}$ & Appropriate & Very good & Available & Very good & $\begin{array}{c}\text { Not } \\
\text { considered }\end{array}$ & Available & Very good & Available & $\begin{array}{c}\text { Not } \\
\text { available }\end{array}$ \\
\hline $\begin{array}{l}\text { Adaptive confrontation } \\
\text { of rock mass properties }\end{array}$ & Very good & Very good & Appropriate & Very good & $\begin{array}{c}\text { Not } \\
\text { considered }\end{array}$ & Available & Available & Appropriate & Appropriate \\
\hline $\begin{array}{c}\text { The harm caused by } \\
\text { displacement }\end{array}$ & $\begin{array}{c}\text { Not } \\
\text { considered }\end{array}$ & $\begin{array}{c}\text { Not } \\
\text { considered }\end{array}$ & Available & Available & $\begin{array}{c}\text { Not } \\
\text { considered }\end{array}$ & Very good & Very good & $\begin{array}{c}\text { Not } \\
\text { considered }\end{array}$ & Available \\
\hline $\begin{array}{l}\text { Possibility of future } \\
\text { strengthening }\end{array}$ & Appropriate & Very good & Appropriate & Very good & $\begin{array}{c}\text { Not } \\
\text { considered }\end{array}$ & Available & Very good & Appropriate & Appropriate \\
\hline $\begin{array}{c}\text { Possibility of stress } \\
\text { preloading }\end{array}$ & Available & Appropriate & Available & $\begin{array}{c}\text { Not } \\
\text { available }\end{array}$ & $\begin{array}{c}\text { Not } \\
\text { considered }\end{array}$ & $\begin{array}{c}\text { Not } \\
\text { available }\end{array}$ & Appropriate & Available & Available \\
\hline $\begin{array}{l}\text { Small support } \\
\text { resistance }\end{array}$ & Very good & Very good & Appropriate & Appropriate & $\begin{array}{c}\text { Not } \\
\text { considered }\end{array}$ & Very good & Available & Appropriate & Available \\
\hline Fast erection speed & Appropriate & Appropriate & Available & Very good & $\begin{array}{c}\text { Not } \\
\text { considered }\end{array}$ & $\begin{array}{c}\text { Not } \\
\text { available }\end{array}$ & Very good & Available & $\begin{array}{c}\text { Not } \\
\text { available }\end{array}$ \\
\hline $\begin{array}{c}\text { Contact } \\
\text { comprehensiveness }\end{array}$ & Appropriate & Very good & Available & Very good & $\begin{array}{c}\text { Not } \\
\text { considered }\end{array}$ & Very good & $\begin{array}{c}\text { Not } \\
\text { available }\end{array}$ & Available & Available \\
\hline Contact tightness & Appropriate & Very good & Available & Very good & $\begin{array}{c}\text { Not } \\
\text { considered }\end{array}$ & Very good & $\begin{array}{c}\text { Not } \\
\text { available }\end{array}$ & Appropriate & Available \\
\hline
\end{tabular}

\subsection{Application of safety monitoring technology}

In the process of urban underground space construction, geotechnical engineering monitoring is the key to fully grasping the overall engineering stress, shape change, support structure, and underwater conditions. At the same time, it is also an important reference for the formulation of geotechnical engineering safety technology scheme and the implementation of safety technology. Based on this, in the construction process, the construction unit needs to strengthen its geotechnical engineering monitoring, so as to timely determine the adverse conditions and take reasonable technical measures for effective treatment, so as to ensure the safety of geotechnical engineering construction in urban underground space. According to the current underground geotechnical engineering construction, its monitoring technology mainly includes direct geometric monitoring, indirect geometric monitoring, and physical monitoring ${ }^{[9,10]}$. Table 3 shows several main underground monitoring technologies of geotechnical engineering and their specific situations. 
Table 3. Main underground monitoring technologies of geotechnical engineering and their specific situations

\begin{tabular}{|c|c|c|c|}
\hline Number & $\begin{array}{l}\text { Monitoring } \\
\text { technology }\end{array}$ & Monitoring items & Equipment or system \\
\hline \multirow[t]{2}{*}{1} & $\begin{array}{l}\text { Direct geometric } \\
\text { monitoring }\end{array}$ & $\begin{array}{l}\text { Horizontal displacement monitoring of } \\
\text { diaphragm wall }\end{array}$ & Fixed gradiograph \\
\hline & & $\begin{array}{l}\text { Spatial shape monitoring } \\
\text { Precise monitoring of geological subsidence }\end{array}$ & $\begin{array}{l}\text { Convergent deformation system } \\
\text { ELBEAM }\end{array}$ \\
\hline \multirow[t]{2}{*}{2} & $\begin{array}{l}\text { Indirect geometric } \\
\text { monitoring }\end{array}$ & Spatial shape monitoring & $\begin{array}{c}\text { GeoMonitor automatic monitoring } \\
\text { system, digital camera }\end{array}$ \\
\hline & & Tunnel shape monitoring & Bassett convergence system \\
\hline 3 & Physical monitoring & Advanced allogeneic monitoring & $\begin{array}{l}\text { Seismic reflection detector, } \\
\text { geological radar }\end{array}$ \\
\hline
\end{tabular}

\section{Conclusion}

In conclusion, the application of geotechnical engineering safety technology is very important in the construction of urban underground space. Therefore, the construction unit must be clear about the urban underground space geotechnical engineering construction and its main safety technical characteristics. Then, based on the actual situation and the actual demand, it is necessary to take reasonable technical measures for safety protection, including the application of environmental safety technology, mechanical equipment safety technology, support safety technology, and monitoring safety technology. Only in this way, the safety of underground geotechnical engineering construction can be ensured, the overall project quality and safety requirements can be met, and sufficient scientific safety guarantee can be provided for the application of urban underground space.

\section{Disclosure statement}

The authors declare that there is no conflict of interest.

\section{References}

[1] Zou X, Wen W, 2021, Safety Technology Analysis of Underground Space Geotechnical Engineering. Bulk Cement, 2021(02): 62-64.

[2] Yang S, Liu F, 2021, Study on Soil and Water Risk Control Countermeasures in the Whole Life Cycle of Underground Section of Municipal Railway. Modern Urban Transit, 2021(01): 18-23.

[3] Zhao Z, 2021, Research on Safety Monitoring Technology of Urban Underground Space Geotechnical Engineering. Engineering and Technological Research, 2021(01): 247-248.

[4] Yi R, Jia K, 2020, Study on the Safety of Urban Underground Space. Geology and Exploration, 2020(05): 1072-1079.

[5] Yuan X, 2020, Evaluation of Geological Environment Suitability of Urban Underground Facilities. Beijing University of Civil Engineering and Architecture.

[6] Meng J, 2020, Research on Safety Risk Pre-control of Underground Engineering Crossing Existing Subway Based on GA-BP. Xi' an University of Architecture and Technology.

[7] Zheng J, 2020, Research on Construction Risk Assessment of Shallow and Long-span Underground Excavation Project. Beijing Jiaotong University. 
[8] Liu Y, 2020, Research on Safety Technology of Geotechnical Engineering in Urban Underground Space. Building Technique Development, 2020(10): 85-86.

[9] Zheng J, 2019, Analysis of the Influence of Groundwater on Urban Underground Engineering Construction. Engineering and Technological Research, 2019(21): 13-14.

[10] Gu L, 2019, Evaluation on Spatial Layout and Construction Safety of Underground Complex of Wuhan Optics Valley Square. Xi'an University of Science and Technology.

Publisher's note

Bio-Byword Scientific Publishing remains neutral with regard to jurisdictional claims in published maps and institutional affiliations. 